Jurnal Sains Farmasi \& Klinis (p- ISSN: 2407-7062 | e-ISSN: 2442-5435)

diterbitkan oleh Ikatan Apoteker Indonesia - Sumatera Barat homepage: http://jsfkonline.org

\title{
Kajian Toksisitas Serbuk Biji Mahoni terhadap Perkembangan Tingkah Laku, Histologi Hati serta Hematologi Anak Mencit
}

(Toxicity studies of mahogany seeds on the development of behavior, liver histology and hematology of mouse pups)

Hilmarni $^{1 *}$, Almahdy A. ${ }^{2}$, \& Helmi Arifin ${ }^{2}$

${ }^{1}$ Akademi Farmasi Imam Bonjol Bukittinggi ${ }^{2}$ Fakultas Farmasi Universitas Andalas

\begin{abstract}
Keywords: swietenia macrophylla; toxycity; histology of
\end{abstract} liver.

Kata kunci: serbuk biji mahoni; swietenia macrophylla; toksisitas.
ABSTRACT: This study aims to determine the effect of seed powder mahogany (Swietenia macrophylla King) on the development of behavior, liver histology and hematology of pups mice. Experimental animals used were 45 female mice were divided randomly into 5 groups. Group 1 as a control group. Groups 2, 3, 4, and 5, respectively mahogany seed powder given at a dose of $5,10,15$, and $20 \mathrm{mg} / 20 \mathrm{~g} /$ day from fetal life until lactation is completed. Developmental toxicity test carried out by behavioral test battery, observation of histology and hematology profile. The results showed that the provision of mahogany seed powder causes abnormal in the conduct reflex test and motor test on post natal day of 8 and 10 , as well as the vision test on post natal day of 14-18. While the observation of liver histology and hematology profile did not show any effect.

ABSTRAK: Penelitian ini bertujuan mengetahui pengaruh pemberian serbuk biji mahoni (Swietenia macrophylla King) terhadap perkembangan tingkah laku, gambaran histologi hati serta profil hematologi anak mencit. Hewan percobaan yang digunakan adalah mencit putih betina sebanyak 45 ekor dibagi secara acak menjadi 5 kelompok. Kelompok 1 sebagai kelompok kontrol diberi NaCMC 0,5\%. Kelompok 2, 3, 4, dan 5 berturut-turut diberi serbuk biji mahoni dengan dosis 5, 10, 15, dan $20 \mathrm{mg} / 20 \mathrm{gBB} /$ hari mulai masa janin hingga masa laktasi selesai. Toksisitas perkembangan dilakukan dengan metoda test perilaku berurutan, observasi terhadap histologi dengan pewarnaan Hematoxilin-Eosin serta penghitungan profil hematologi. Hasil penelitian menunjukan pemberian serbuk biji mahoni menyebabkan penyimpangan tingkah laku pada uji refleks dan uji motorik PND-8 dan PND-10, serta pada uji penglihatan PND-14 hingga PND18. Sedangkan pada pengamatan histologi hati dan profil hematologi anak mencit tidak menunjukan adanya pengaruh.
${ }^{*}$ Corresponding Author: Hilmarni (Akademi Farmasi Imam Bonjol Bukittinggi, Jl. Kesehatan No 20 Bukittinggi, Sumatera Barat) email: hilmarniafzan@gmail.com
Article History:

Received: 10 Mar 2015 Accepted: 27 Oct 2015

Published: 1 Nov 2015 Available online: 30 Dec 2015 


\section{PENDAHULUAN}

ASI merupakan makanan yang paling sempurna bagi bayi. Keunggulan ASI yang bersih, selalu segar, warna, bau, rasa, dan komposisi yang tidak dapat ditiru oleh susu lain bukan hanya merupakan sumber zat gizi bagi bayi juga dapat mencegah morbiditas, mendorong perkembangan sensorik dan kognitif yang optimal, dan mengurangi risiko beberapa penyakit kronis [1]. Oleh karena itu, ASI tidak hanya diberikan selama 6 bulan pertama. Organisasi kesehatan dunia (WHO) merekomendasikan ASI terus dilanjutkan sampai bayi berusia 2 tahun atau lebih, dengan disertai makanan pendamping ASI.

Melihat periode menyusui yang cukup lama ini, seorang ibu dapat mengalami berbagai keluhan atau gangguan kesehatan yang membutuhkan obat. Banyak ibu hamil atau ibu yang sedang menyusui menggunakan obat-obatan yang dapat memberikan efek yang tidak dikehendaki pada bayi yang disusuinya. Salah satunya penggunaan obatobat tradisional.

Salah satu dari sekian banyak tumbuhan yang berkhasiat sebagai obat yaitu tumbuhan mahoni (Swietenia macrophylla King). Penggunaan secara tradisional diyakini memberikan efek untuk pengobatan hipertensi, malaria [2,3,4] dan juga untuk menghilangkan rasa sakit [5]. Penyakit kulit dan luka juga dapat diobati dengan menggunakan rebusan biji [6]. Selain itu, biji juga digunakan untuk mengurangi diare [7].

Dari biji S. macrophylla, berbagai jenis limonoid yang dikenal juga sebagai tetranortriterpenoid. Diantaranya swietenine, swietenolide (senyawa pahit), 8,30-epoksi-swietenine asetat, swietenolide diasetat [2], augustineolide dan 3ß,6dihydroxydihydrocarapin [8]. Di samping itu juga ditemukan beberapa asam lemak dan terpenoid [2].

Untuk pengembangan obat tradisional menjadi fitofarmaka, diperlukan beberapa tahapan pengujian keamanan dan khasiat secara praklinis dan klinis [9]. Selaian pemastian secara efek farmakologis dari tumbuhan tersebut, diperlukan juga uji keamanan penggunaannya karena banyak anggapan bahwa obat tradisional aman dikonsumsi dan tidak beresiko terhadap kesehatan, namun dapat menyebabkan efek yang merugikan jika produk yang digunakan berkualitas rendah atau digunakan tidak sesuai aturan [10].

Oleh karena itu, penelitian ini bertujuan untuk melihat efek toksik yang mungkin terjadi dengan melihat perkembangan tingkah laku anak mencit, profil hematologi, dan histopatologi hati pada anak mencit yang terpapar serbuk biji mahoni selama masa laktasi.

\section{METODE PENELITIAN}

Alat

Alat-alat yang digunakan adalah timbangan hewan, kandang mencit, kaca objek, cover glass, mikroskop listrik, timbangan analitik, batang pengaduk, lumpang stanfer, pinset, kamera digital, kaca arloji, jarum oral, gelas ukur, pipet tetes, pipet mikro, tissue, tabung reaksi, label, mikrotube, sentrifuge, vacuumtainer tubes with $\mathrm{K}_{2} \mathrm{EDTA}$, auto hematology analyze SISMEX.

\section{Bahan}

Biji mahoni diperoleh dari Kebun Tanaman Obat Universitas Andalas, NaCMC 1\%, mencit putih betina dan jantan, larutan $\mathrm{NaCl}$ fisiologis, larutan bouin's, alkohol 96\%, xylol, paraffin, zat warna hematoksilin, eosin, pewarna giemsa, methanol.

\section{Cara Kerja}

\section{Tahapan Penelitian}

Sampel yang digunakan adalah biji mahoni yang sudah tua dan sudah dikeringkan kemudian 
dihaluskan, dan disuspensikan dengan NaCMC 0,5\%. Hewan yang digunakan adalah mencit putih betina (umur 2 bulan) dan diaklimatisasi selama 10 hari. Pengawinan hewan dilakukan pada masa estrus, jika ditemukan sumbat vagina mencit dianggap berada kehamilan hari ke-o [11]. Mencit dikelompokan menjadi 5 kelompok yang masingmasingnya terdiri dari 9 ekor. Kelompok perlakuan kontrol diberi Na.CMC. Dosis yang digunakan untuk kelompok uji adalah 5, 10, 15 dan $20 \mathrm{mg} /$ $20 \mathrm{gBB} /$ hari. Sediaan uji diberikan mulai pada hari ke 15 kehamilan hingga masa laktasi selesai pada hari ke-21.

\section{Studi Toksisitas Perkembangan (Tingkah Laku)}

Perkembangan perilaku anak mencit diamati mulai umur 5 hari sampai 21 hari dengan metode Test Perilaku Berurut (Behavioral Test Battery). Parameter yang diamati adalah persentase keberhasilan kemampuan refleks, kemampuan motorik, kemampuan sensorik, dan berat badan anak mencit. Anak mencit berasal dari induk yang dibiarkan melahirkan secara spontan.

\section{Uji kemampuan refleks [12] \\ Refleks membalikan badan}

Uji ini dilakukan pada anak mencit berumur 5 hari. Anak mencit yang akan diuji diletakan terlentang di tempat yang datar. Waktu yang dibutuhkan anak mencit untuk mengubah posisi dari posisi terlentang ke posisi telungkup dicatat dengan stopwatch.

\section{Refleks menghindari jurang}

Pengamatan dilakukan pada anak mencit berumur 6 hari. Anak mencit yang akan diuji diletakan di atas meja datar, tangan dan hidung diletakkan sejajar di tepi meja tempat anak mencit itu berada. Kemudian diamati reaksi anak mencit dan dicocokan dengan skor. Laju keberhasilan dihitung dengan cara mengamati berapa persen anak mencit yang mampu menghindari jurang.

\section{Refleks geotaksis negatif}

Pengamatan dilakukan pada anak mencir berumur 7 hari. Anak mencit yang akan diuji diletakan pada suatu tempat miring dengan sudut kemiringan $25^{\circ}$, kemudian diamati reaksinya dan dicocokan dengan skor. Laju keberhasilan dihitung dengan cara mengamati berapa persen anak mencit yang mampu menahan berat tubuhnya dan memutar posisi tubuhnya.

\section{Uji kemampuan motorik [12] \\ Perkembangan kemampuan berenang}

Pengujian dilakukan terhadap anak mencit berumur 8, 10 dan 12 hari. Anak mencit tersebut dijatuhkan ke dalam bejana berisi air hangat $\left(27^{\circ}\right.$ - $\left.30^{\circ} \mathrm{C}\right)$, kemudian diamati gerakannya, hasil pengamatan dicocokan dengan skor berdasarkan: Posisi sudut kepala, Arah berenang, Penggunaan anggota badan

\section{Perkembangan kemampuan mengangkat badan dan anggota belakang}

Pengujian dilakukan pada anak mencit berumur 7 hari sampai seluruh anak mencit yang diamati mampu mengangkat badan dan anggota belakangnya sehingga tidak terjatuh. Anak mencit yang akan diuji, tangannya diletakan pada kawat dengan diameter $2 \mathrm{~mm}$, panjang $20 \mathrm{~cm}$ yang direntangkan diantara 2 tiang kayu setinggi $30 \mathrm{~cm}$, kemudian diamati berapa persen anak mencit yang dapat menggenggam (grasping) dan mengangkat badan serta kakinya, sehingga tidak terjatuh.

\section{Uji kemampuan sensorik [12]}

\section{Perkembangan kemampuan penciuman}

Pengamatan dilakukan terhadap anak mencit berumur 21 hari. Anak mencit digenggam supaya diam, lalu hidungnya didekatkan ke batang kapas (cotton bud) yang telah dicelupkan kedalam 
cologne. Hasil positif bila anak mencit menghindar dan negatif bila diam saja.

\section{Perkembangan kemampuan penglihatan}

Pengamatan dilakukan pada anak mencit mulai berumur 7 hari sampai seluruh anak mencit memberikan tanggapan positif terhadap uji ini. Anak mencit dipegang ujung ekornya dan didekatkan pada tongkat horizontal dan dijaga misalnya tidak menyentuh tongkat. Hasil pengujian dinilai positif bila anak mencit yang diuji mampu meraih tongkat.

\section{Perkembangan kemampuan pendengaran}

Pengamatan dilakukan pada anak mencit mulai berumur 7 hari sampai seluruh anak mencit memberikan tanggapan positif terhadap uji ini. Tanggapan dinilai positif bila anak mencit tersentak pada saaat kedua batang logam dipukul secara diam-diam di atasnya. Anak mencit yang belum mendapat giliran harus dijauhkan dari tempat pengamatan agar tidak terbiasa (terhabituasi) dengan rangsangan bunyi yang akan diberikan.

\section{Pemeriksaaan Mikroskopis Preparat Histologi Hati} Anak Mencit

Pengambilan organ hati dilakukan terhadap anak mencit dari 3 ekor induk pada usia ke-O, 7, 14 dan 21 setalah kelahiran kemudian dilakukan pemeriksaan histologi hati. Pembuatan preparat histologi hati anak mencit dilakukan dengan metoda Hematoksilin-eosin dan kemudian diamati bentuk vena sentralis (lingkaran utuh/putus), sinusoid (utuh/membesar), hepatosit (teratur membentuk lempeng sel/tidak teratur), nukleus (bulat/pecah/hilang).

\section{Pemeriksaan Hematologi}

Darah dikumpulkan dengan cara tusuk jantung terhadap 3 ekor anak mencit yang berusia ke-5, 10,
15, 20 dari masing-masing kelompok uji, dimana sebelum dilakukan pengambilan darah anak mencit terlebih dahulu di anestesi dengan eter. Darah tersebut ditampung dalam tabung darah vacuum yang sudah berisi EDTA. Pemeriksaan profil hematologi dilakukan dengan cara automatic yang menggunakan alat auto hematology analyzer.

\section{Analisis Data}

Seluruh data induk dan anak mencit dianalisis dengan menggunakan uji analisis variasi (ANOVA), jika hasilnya berbeda nyata dengan kontrol dilanjutkan dengan uji lanjut Duncan. Khusus untuk histologi ditampilkan dalam bentuk gambar dengan analisis deskripsi.

\section{HASIL DAN DISKUSI}

Setelah dilakukan penelitian toksisitas serbuk biji mahoni terhadap perkembangan tingkah laku, histologi hati dan profil hematologi anak mencit diperoleh hasil sebagai berikut:

Berdasarkan uji statistik yang telah dilakukan disimpulkan bahwa berat badan anak mencit pada usia ke-1 dan ke-7 dari kelompok pemberian serbuk biji mahoni kelompok perlakuan dosis berpengaruh secara bermakna jika dibandingkan dengan kelompok kontrol $(\mathrm{p}<0,05)$. Variasi berat badan anak mencit pada usia ke-1 disebabkan pada masa ini anak lebih sering menyapih susu dari induk yang terpapar serbuk biji mahoni dan diperkirakan pemberian sediaan uji dapat mempengaruhi ekskresi ASI sehingga berkurangnya suplai nutrisi pada anak mencit.

Berdasarkan hasil uji statistik terlihat ada perbedaan bermakna terhadap kemampuan membalikan badan, dan geotaksis negatif anak mencit jika dibandingkan kelompok dosis kontrol $(\mathrm{p}<0,05)$, sedangkan untuk kemampuan menghindari jurang tidak ada pengaruh terhadap kelompok uji ( $p>0,05)$. 


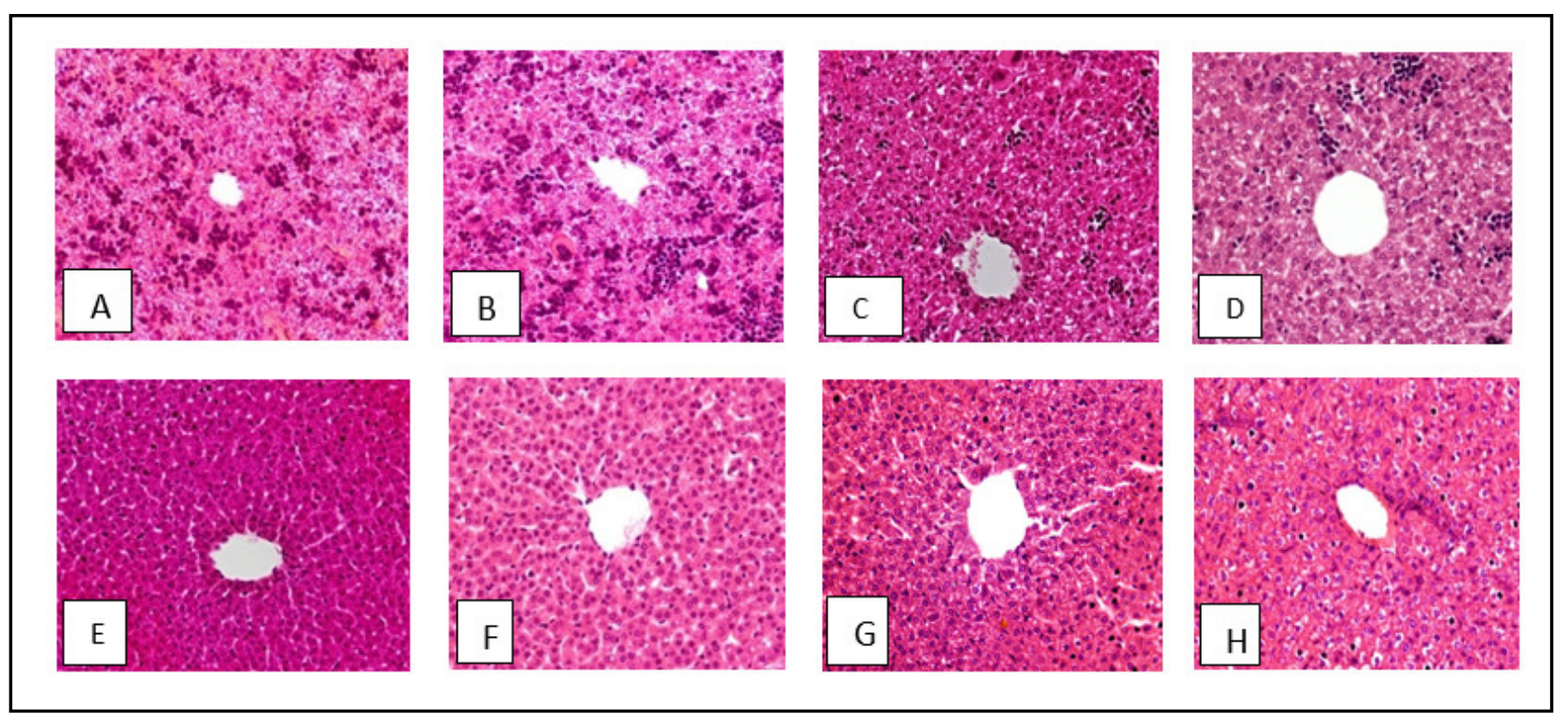

Gambar 1. Gambaran histopatologi Organ Hati Anak Mencit (A) Kontrol negatif usia ke-0, Sel hepatosit belum teratur, vena sentralis belum utuh, banyak sel hamatopoesis, (B) Kelompok perlakuan usia ke-0, Sel hepatosit belum teratur, vena sentralis belum utuh, banyak sel hamatopoesis, (C) Kontrol negatif usia ke-7, Sel hepatosit belum teratur, vena sentralis mulai utuh, sel endotelium mulai terlihat,sel hamatopoesis sudah mulai berkurang, (D) Kelompok perlakuan usia ke-7, Sel hepatosit belum teratur, vena sentralis mulai utuh, sel endotelium mulai terlihat,sel hamatopoesis sudah mulai berkurang, (E) Kontrol negatif usia ke-14, Sel hepatosit belum teratur, vena sentralis mulai utuh, sel endotelium mulai terlihat,sel hamatopoesis tidak ada, (F) Kelompok perlakuan usia ke-14, Sel hepatosit belum teratur, vena sentralis mulai utuh, sel endotelium mulai terlihat,sel hamatopoesis tidak ada, (G) Kontrol negatif usia ke-2 1, Sel hepatosit belum teratur, vena sentralis utuh, sel endotelium dan sel kupffer mulai terlihat, mulai mitosis sel, (H) Kelompok perlakuan usia ke-21, Sel hepatosit belum teratur, vena sentralis utuh, sel endotelium dan sel kupffer mulai terlihat, mulai mitosis sel.

Pada pengujian ini kemampuan berenang anak mencit dengan pemberian serbuk biji mahoni dengan variasi kelompok perlakuan dosis yang telah ditetapkan selama masa janin hingga masa laktasi selesai memperlihatkan ada perbedaan kemampuan berenang anak mencit terhadap posisi sudut kepala dan arah berenang serta penggunaan anggota badan jika dibandingkan dengan kelompok kontrol. Namun secara statistik perbedaan tersebut pada posisi sudut kepala dan arah berenang pada hari ke-8 setalah lahir (PND8) dan PND-10 ( $<<0,05)$, dan pada penggunaan anggota tubuh memberikan perbedaan yang bermakna dengan kelompok kontrol negatif PND$8(\mathrm{p}<0,05)$. Hal tersebut dikarenakan pemberian serbuk biji mahoni sedikit mempengaruhi sistem ekstrapiramidal (korteks serebrum basal ganglia yang terdiri dari necleuscaudatus, nucleus lentiformis dan globus pallidus) yang merupakan pusat gerakan bawah sadar. Fungsinya antara lain memelihara posisi tubuh normal dan mengatur tonus otot [13]. Pada perkembangan penglihatan, pada semua kelompok dosis memperlihatkan perbedaan dibanding dengan kelompok kontrol, secara statistik memperlihatkan adanya pengaruh terhadap kemampuan penglihatan kelompok perlakuan dengan kelompok kontrol pada PND$14,15,16,17,18(\mathrm{p}<0,05)$. Fungsi penglihatan berhubungan erat dengan retina. Retina mengandung selapis sel fotoreseptor (sel kerucut dan sel batang) yang peka terhadap berkas cahaya yang melalui lensa. Saraf yang keluar dari retina adalah saraf (sensoris) aferen yang menghantar impuls cahaya dari fotoreseptor melalui nervus optikus ke otak untuk interpretasi visual [14].

Perubahan struktural hepatosit pada variasi dosis perlakuan tidak menunjukan perbedaan secara nyata jika dibandingkan dengan jaringan hati mencit kontrol, dimana selama pemeriksaan histologi hati postnatal, karakteristik hepatosit 


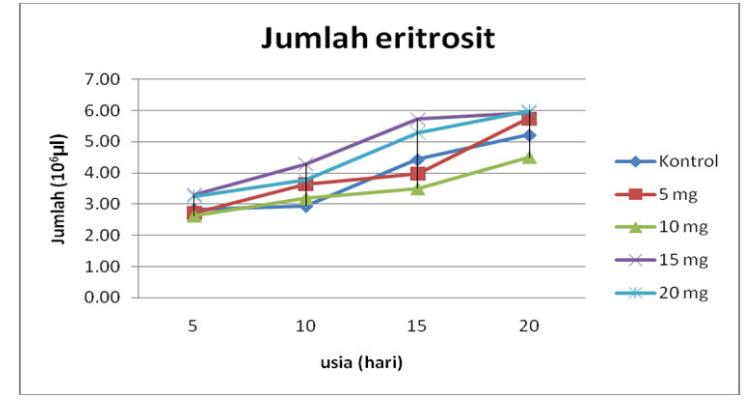

Gambar 3. Jumlah eritrosit anak mencit

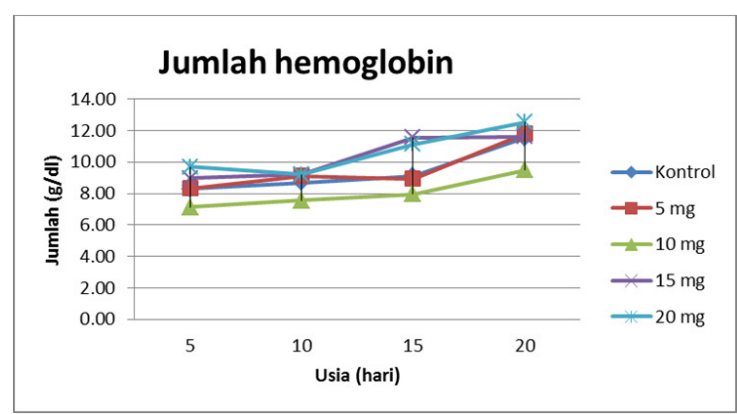

Gambar 4. Jumlah hemoglobin anak mencit

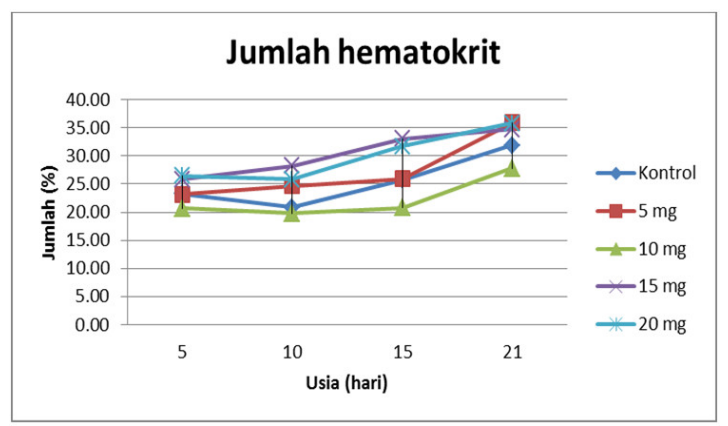

Gambar 5. Jumlah hematokrit anak mencit

belum sepenuhnya sempurna hingga 2 - 3 minggu setelah lahir [15]. Minggu pertama setelah kelahiran, sel hematopoietik terdistribusi pada hati neonatal pada dasarnya sama dengan pada janin.

Hasil pengukuran eritrosit, $\mathrm{Hb}$, hematokrit rata-rata anak mencit pada hari ke- 5 sampai hari ke-21 relatif lebih rendah dibandingkan dengan kontrol negatif, namun mengalami peningkatan pada masing-masing kelompok. Hasil uji statistik menunjukan kadar eritrosit, Hb, Hematokrit rerata pada kelompok perlakuan variasi dosis menunjukan perbedaan yang bermakna $(p<0,05)$. Hasil uji lanjut Duncan menunjukan kelompok perlakuan dosis $15,20 \mathrm{mg} / 20 \mathrm{gBB}$ berbeda secara bermakna dengan kelompok kelompok kontrol negatif.

Anemia dapat ditimbulkan oleh penurunan eritrosit, hemoglobin serta hematokrit sehingga kapasitas darah mengangkut oksigen menurun untuk memenuhi kebutuhan jaringan. Penyebab anemia salah satunya gangguan pembentukan sel darah merah akibat keadaan defisiensi besi. Anemia defisiensi besi terjadi saat kebutuhan besi paling besar, seperti pada masa bayi, remaja dan kehamilan. Anemia defisiensi besi adalah suatu gejala, bukan entitas penyakit primer. Pada bayi, Hb turun dengan cepat setelah lahir dan pada akhir periode neonatal (4 minggu setelah lahir), jumlah $\mathrm{Hb}$ dapat serendah 10.0g / dL dibarengi dengan hemolisis eritrosit. Dengan demikian perubahan yang kompleks yang terjadi dalam periode neonatus membuat perbedaan antara fisiologi dan patologi menjadi sulit dibedakan [16].

Jumlah rerata leukosit pada kelompok perlakuan dosis $15 \mathrm{mg} / 20 \mathrm{gBB}$ juga mengalami peningkatan pada hari ke-10 dan mengalami penurunan pada hari ke-15 dan hari ke-20 dibandingkan dengan kelompok kontrol negatif. Hasil uji stastistik menunjukan jumlah rerata leukosit per hari pada kelompok perlakuan dosis dibandingkan dengan kontrol negatif menunjukan perbedaan yang tidak bermakna $(p>0,05)$. Sedangkan untuk pemeriksaan jumlah leukosit diferensial tidak menunjukan perbedaan yang bermakna antara kelompok kontrol dengan kelompok perlakuan $(\mathrm{p}>0,05)$.

\section{KESIMPULAN}

Pemberian serbuk biji mahoni dengan variasi dosis yang diberikan pada masa janin hingga masa laktasi selesai menyebabkan penyimpangan tingkah laku anak mencit pada uji refleks (membalikkan tubuh dan geotaksis negatif), uji 
motorik (kemampuan berenang dan mengangkat anggota badan) dan pada uji kemampuan sensorik (kemampuan penglihatan PND-14 hingga PND18). Pemberian serbuk biji mahoni dengan variasi dosis yang ditetapkan tidak mempengaruhi nilai hematologi rutin anak mencit. Secara mikroskopis, kerusakan jaringan hati pada anak mencit kelompok perlakuan dosis 5, 10, $15 \mathrm{dan} 20 \mathrm{mg} / 20 \mathrm{gBB} /$ hari tidak berbeda secara nyata dibandingkan dengan kelompok kontrol negatif. Kelainan yang ditemukan disebabkan karena sel hati anak mencit masih dalam perkembangan.

\section{DAFTAR PUSTAKA}

1. Butte, N. F., Lopez-Alarcon, M. G., \& Garza, C. (2002). Nutrient adequacy of exclusive breastfeeding for the term infant during the first six months of life. World Health Organization, Geneva.

2. Chan, K. C., Tang, T. S., \& Toh, H. T. (1976). Isolation of swietenolide diacetate from Swietenia macrophylla. Phytochemistry, 15(3), 429-430.

3. Chen, J. J., Huang, S. S., Liao, C. H., Wei, D. C., Sung, P. J., Wang, T. C., \& Cheng, M. J. (2010). A new phragmalin-type limonoid and anti-inflammatory constituents from the fruits of Swietenia macrophylla. Food chemistry, 120(2), 379-384.

4. Kadota S., Marpaung, L., Kikuchi, T., Ekimoto, H. (1990). Constituents of the seeds of Swietenia mahagoni Jacq. I. Isolation, structures, and $1 \mathrm{H}$-and $13 \mathrm{C}$-nuclear magnetic resonance signal assignments of new tetranortriterpenoids related to swietenine and swietenolide. Chemical and Pharmaceutical Bulletin, 38(3), 639-651.

5. Goh, B. H., \& Kadir, A. H. (2011). In vitro cytotoxic potential of Swietenia macrophylla King seeds against human carcinoma cell lines. Journal Medicinal Plants Research, 5(8), 1395-1404.

6. SeokKeik, T., Osman, H., KengChong, W., PengLim, B., \& Ibrahim, P. (2009). Antimicrobial and antioxidant activities of Swietenia macrophylla leaf extracts. Asian Journal of Food and Agro-Industry, 2(2), 181-188.

7. Maiti, A., Dewanjee, S., \& Mandal, S. C. (2007). In vivo evaluation of antidiarrhoeal activity of the seed of Swietenia macrophylla King (Meliaceae). Tropical journal of pharmaceutical research, 6(2), 711-716.

8. Mootoo, B. S., Ali, A., Motilal, R., Pingal, R., Ramlal, A., Khan, A., ... \& McLean, S. (1999). Limonoids from Swietenia macrophylla and S. aubrevilleana. Journal of natural products, 62(11), 15141517.

9. Badan Pengawas Obat dan Makanan Departemen Kesehatan Republik Indonesia. (2005). Kriteria dan Tatalaksana Pendaftaran Obat Tradisional, Obat Herbal Terstandar dan Fitofarmaka, Jakarta.
10. WHO. (2002). Drug Information (3rd ed.). Geneva.

11. Manson, J. M., Zenick, H., \& Costlow, R. D. (1982). Teratology Test Methods for Laboratory Animals, New York.

12. Tanaka, T. (2012). Reproductive and neurobehavioral effects of clothianidin administered to mice in the diet. Birth Defects Research Part B: Developmental and Reproductive Toxicology, 95(2), 151-159.

13. Pearce, E. C. (2009). Anatomi dan Fisiologi Untuk Paramedis, Gramedia, Jakarta.

14. Eroschenko, V. P. (2000). Difiore's Atlas of Histology With Functional Correlations Ed.9, Lippincott Williams \& Wilkins Inc, USA.

15. Apte, U., Zeng, G., Thompson, M. D., Muller, P., Micsenyi, A., Cieply, B., ... \& Monga, S. P. (2007). $\beta$-Catenin is critical for early postnatal liver growth. American Journal of PhysiologyGastrointestinal and Liver Physiology, 292(6), G1578-G1585.

16. Provan, D., Singer, C. R. J., Baglin, T., \& Lilleyman, J. (2004). Oxford Handbook of Clinical Haematology, Second edition, Queen Mary's School of Medicine and Dentistry, University of London. 